\title{
Obstacles of New Manufacturing Systems in Libya: Reconnaissance Study in Libyan Environment
}

\author{
Entsar Kouni Mohamed Albishti \\ Faculty of Accounting, Zawia University, Zawia, Libya \\ Email: zhrkb@yahoo.com
}

How to cite this paper: Albishti, E.K.M. (2022) Obstacles of New Manufacturing Systems in Libya: Reconnaissance Study in Libyan Environment. Open Access Library Journal, 9: e8345.

https://doi.org/10.4236/oalib.1108345

Received: December 31, 2021

Accepted: January 22, 2022

Published: January 25, 2022

Copyright $\odot 2022$ by author(s) and Open Access Library Inc.

This work is licensed under the Creative Commons Attribution International License (CC BY 4.0).

http://creativecommons.org/licenses/by/4.0/

(c) (i) Open Access

\begin{abstract}
Recently, all businesses and manufacturing environment's competition depend on the highest quality of its products and lowest cost. Many modern systems such as total quality management and just-in-time system change the global competitive business environment, which has forced the organization to transform to achieve their goals. These systems focus on the concept of human resource development and quality improvement. It appears that the Libya manufacturing management may not quite understand what the new and modern systems are, and what is involved in implementing new systems. Therefore, it is necessary to try to benefit from them in improving the production by taking into consideration the difficulties that Libya struggled in the last decade. In order to achieve the paper objectively, an interview was made with some responsible people in different industrial companies, to investigate the availability of new manufacturing systems in Libya, and the obstacles that they may face. The researcher hopes that the paper results will be helpful in reaching decisions to develop the industrial sector, through adopting new manufacturing methods, in order to increase the growth in this sector in Libya.
\end{abstract}

\section{Subject Areas}

Economics

\section{Keywords}

TQM: Total Quality Management, IM: Inventory Management,

JIT: Just-in-Time, MENA: Middle East and North Africa Countries,

MS: Management Support

\section{Introduction}

The challenge to achieving sustainable development of the Libyan industry is to 
develop manufacturing systems to improve the management of the most productive public enterprises. To achieve that objective, a high level of change is required, which demands a strong and healthy industry sector capable of attracting more foreign industries and upgrading of domestic. For instance, the philosophy of a just-in-time system maintains that a manufacturing floor is laid out by product rather than by function. All equipment should dedicate to a product or family of products and organized logically in the order, in which the various processes are performed on that family of products. This production strategy is to reduce the process, by new methods to manage the consequences of the change because inventory reduction is the center of this system, which raises the level of risk, in addition to other problems that may result [1] [2]. This system will be guided to develop production stages to get high product quality and apply the concept of total quality management TQM, it represents the real guarantee to reduce the cost, increase manufacturing flexibility and increase efficiency [3] [4].

Furthermore, to understand the significance of this subject, this paper tries to know the obstacles that hinder the new manufacturing program application in Libya such as; JIT in manufacturing system and TQM, which still depends on traditional manufacturing systems: trying to give some flexibility in improving products quality and lower cost. In doing so, exploring the solutions may help in benefit of these new manufacturing program applications.

\section{Statement Problem}

The lack of high-level quality products is one of the problems that face the competitive position of industrial products in Libya. Given what has been mentioned in the literature about production methods, many studies showed that whenever the company is more efficient, least amount of inputs is required to produce outputs, so it results in less production cost and high quality [5]. However, the most important problem for products industries in Libya is using a huge amount of the material, and a big number of workers to produce fewer outputs [6]. Thus, the need of increasing the capacity and improving the products' competitiveness by applying new manufacturing systems is the main reason to search in this and find answers to the following question:

Are there enough requirements for new manufacturing systems adoption in Libyan industry environment, and what are the obstacles that are faced in the new manufacturing system application?

\section{Study Objective}

1) Investigate the availability of new modern systems in the Industrial Libyan Environment.

2) Addresses the main obstacles that would influence the adoption of these systems in Libyan environment.

\section{Data Collection Method}

This paper, based on interviews with many responsible people in a Libyan in- 
dustrial environment (oil, cement, and paper companies) regarding the problems that are believed to affect the adoption of some new and modern systems such as just-in-time system and total quality management system. A thematic network was used to analyze the qualitative data. The result indicated that the manufacturing system is still using antiquated methods and the most obstacles were as follows (Table 1 and Table 2).

Details are, however explored in the excerpts below.

Table 1. Respondents' answers.

\begin{tabular}{|c|c|c|}
\hline \multicolumn{3}{|c|}{ Q: What are the problems that face the change to the new manufacturing system in Libya? } \\
\hline Respondents 1 & Finding & Discussion \\
\hline 2 & Material, Supplier & First, the majority of those interviewed have assumed that the raw \\
\hline 3 & Material, suppliers \& Financial, Experts & materials and suppliers make the adoption impossible, because many \\
\hline 4 & $\begin{array}{l}\text { Material. suppliers \& Unclear Benefit, } \\
\text { Experts }\end{array}$ & $\begin{array}{l}\text { kinds of raw material should be available, not just one or two kinds, } \\
\text { which means that the overseas suppliers are the most crucial factors } \\
\text { behind, the absence of any new system. Furthermore, the opinion of }\end{array}$ \\
\hline 5 & Managers support, financial & $\begin{array}{l}\text { Adeyemi, } 2010 \text { [7] about the transportation strategy may be helpful in } \\
\text { Libyan situation. }\end{array}$ \\
\hline 6 & $\begin{array}{l}\text { Unclear benefit, Technology, Experts, } \\
\text { suppliers }\end{array}$ & $\begin{array}{l}\text { Second, about } 41.6 \% \text { of the respondents stated that a lack of financial } \\
\text { resources is the cause behind this matter. In brief, the absence of the }\end{array}$ \\
\hline 7 & Financial \& Material \& suppliers & $\begin{array}{l}\text { vital governmental support has negatively affected this sector in having } \\
\text { any development. }\end{array}$ \\
\hline 8 & Experts, Financial, Material, suppliers & Third, the same percentage of the respondents has attributed the \\
\hline 9 & Technology, Experts, Material suppliers & $\begin{array}{l}\text { non-existence of new systems to the absence of the experts. } \\
\text { Forth } 25 \% \text { of respondents stated that the technology is the reason }\end{array}$ \\
\hline 10 & Special condition & $\begin{array}{l}\text { Forth, } 25 \% \text { of respondents stated that the technology is the reason. } \\
\text { Fifth, about } 16.66 \% \text { of the related participants have attributed this }\end{array}$ \\
\hline 11 & Financial resources & $\begin{array}{l}\text { matter to the difficulties to the unclear benefits and managers' support. } \\
\text { A sixth, a small percentage of the interviewees have demonstrated that a } \\
\text { lack of enough manager's support is the most obstacles that hinder the } \\
\text { implementation. }\end{array}$ \\
\hline 12 & $\begin{array}{l}\text { Technology, Managers support, } \\
\text { Material, suppliers }\end{array}$ & $\begin{array}{l}\text { Seventh, in comparison, less than } 8.3 \% \text { of the interviewees have described } \\
\text { the reasons of this matter are the need of some special condition for the } \\
\text { kinds of industries, as a lack of many necessary elements. These views } \\
\text { were also, supported by the researcher's observation in doing some } \\
\text { visits to the locations of some factories in Libya. }\end{array}$ \\
\hline
\end{tabular}

Table 2. The response rate.

\begin{tabular}{ccc}
\hline Reasons & Frequencies & Percent \\
\hline Material \& suppliers & 8 & $66 \%$ \\
Financial resources & 5 & $41.66 \%$ \\
Experts & 5 & $41.66 \%$ \\
Technology & 4 & $25 \%$ \\
Unclear benefits & 2 & $16.66 \%$ \\
Managers support & 2 & $16.66 \%$ \\
Special condition & 1 & $8.3 \%$ \\
\hline
\end{tabular}




\subsection{Materials and Overseas Suppliers}

Respondents 1 disclosed that suppliers are demonstrably the most problems that faced in any new system. Respondents 12 explained that the suppliers have considered the main problems that faced in the Libyan industries. They explained that changing to any new system such as JIT would require excellent material, which means multi-delivery; the cost will be very high.

Moreover, Respondent 8 said that the application of TQM or JIT or any other system would not be possible because of the need for suppliers in the local environment.

Indeed, this finding is in line with many studies, which pointed that trading off reduced the inventory against a higher transportation cost, becomes the critical factor for the total cost minimization. For instance, the JIT approach allows a small margin for the transportation cycle variation to avoid the production processes. In addition to, the external factors on whether congestion and unexpected accidents could cause a serious delay that leads to a negative effect [8].

\subsection{Financial Resources}

According to one interviewee, a lack of financial resources is one of the most crucial factors of any new system implementation. One respondent stated that the main problem is that the cost of adoption is high taking into consideration that Libya developing country. Applying the new manufacturing method will cost the industry sector a lot, and that needs government financial support.

This claim is supported by the fact that the high cost of the change bans the implementation decision. This answer gives evidence of the importance of financial sources that are needed for the systems' application, and reflects the most challenging to the implementation decision that typically supplied virtually in all developing countries. As mentioned in previous studies that some company managers do not accept the idea of change due to the high cost in the beginning, such as training cost, contracts and others [9].

\subsection{Technology and Experts}

The respondents further lamented that a lack of technology is the recurrent crisis in and around JIT and TQM, as revealed by interviewee 6, when he insisted that to apply new manufacturing system, there should be the needed technology to change the production system or the application will fail. This point supported the paper problem that the production system is very old. According to him, the factories do not apply modern system in their manufacturing system. The main problems are a lack availability of new machines because the experts that can depend on implementing new systems are available, which supported the finding of Elbishti, study 2015 which stated that there are enough experts about JIT or others implementation.

\subsection{Unclear Benefits}

Other interviews with respondents illustrated that, the main problem is unclear 
benefits of the new systems in a short term, which makes the superior management ban the decision for now.

In the same vein in an interview conducted with respondents 4 , claimed that the application in the current stage would be a failure, especially if the benefits of change cannot recognize. Therefore, the superior management needed to be more attentive to the updated operations management technology to can develop the appropriated strategy that might help in change, in order to become more efficient in driving the implementation steps.

\subsection{Managers Support}

Based on the above assertion, it can establish through the findings of the interview that a little less one-fourth of the respondents see that the absence of leadership support negatively affects the implementation decision. According to one respondent, it is necessary to convince the superior managers by this idea first to have enough support and search for a way to provide the whole structure that needed for implementation, then start to plan the change in many stages to ensure its implementation steps. This fact pointed by Hokoma in 2010 [10] that the management body should be more attentive to the updated operations management technology.

\subsection{Special Condition}

According to respondent 10, the production system is still a traditional system and in the current situation, it is impossible to apply JIT or any other system; many kinds of industry need special care. For example, the materials need to keep in a special condition, such as the correct temperature to avoid damage. This is a very difficult issue for eliminating material warehouses. This means that the management needs to take immediate and strategic actions, in order to improve their manufacturing and managerial operations of this kind of industry to achieve successful and effective adoption. This, in fact, agreed with Kumar [11] [12] opinion, who stated that, the management should pay more attention to applying for the most reliable programs and provide more support and flexibility to implement the related up-to-date techniques and technologies throughout their companies.

\section{Results and Discussion}

Most of those interviewees have believed that the overseas suppliers are crucial factors behind the absence of any new industrial system. Some of them insisted that the local suppliers would be the only way to apply it. In contrast, the other believed that the transportation strategy would have a great impact in a short term. Other respondents stated that a lack of financial resources is behind this matter.

In the light of this, half of those respondents believed that it is difficult to overcome; however, the other asserted that government actions towards such kinds of those problems are required. They revealed that the restructuring mon- 
etary should include a new role to achieve the goals of the development growth.

In brief, the absence of the vital governmental role in implementing effective and sufficient production programs has negatively affected those related factories in having any development. Moreover, more than $16 \%$ of the respondents have attributed the non-existence of new programs to the absence of the manager's support.

In answering this question, a small percentage of those questioned asserted that in a short-term, there would be big risks on their factories to make the change.

The related participants have attributed this matter to the lack of technology, in addition to the special condition that these industries need, and difficulties of recognizing the benefits. However, in a long run adoption of new systems and methods will accelerate structural shifts toward a stronger and more sustainable economic future. Although the superior management of factories gradually started steps toward the development, such as making contracts to import new machines and equipment in the factories, it did not do a real action to plan the implementation because of the high cost problem to supply the other requirements besides the main problems, which are overseas suppliers, and lack of government support.

Finally, the findings of this paper agreed with the findings conducted by many authors such as [2] [13] [14] [15] [16] [17].

\section{Contribution to Knowledge}

1) The Libyan industry, in the long term, will benefit from increasing the growth in the industrial sector. It will determine the relationship between applying the new industrial ways and financial growth, like many other MENA countries.

2) This paper could consider as a step towards raising and improving the comprehension of the management of industrial companies in Libya by providing recommendations to overcome the difficulties that face the changing steps in Libya.

3) This paper provides an example to invite the industrial companies in Libya to apply and accommodate the essential elements and requirements for change application.

\section{Conclusions}

In order to achieve this paper's objective, the theoretical, methodological and empirical studies undertaken to explore the problems that hinder change application in the manufacturing systems in Libya. Much of the evidence from the interview indicates that Libyan industry still operates using old methods, which makes their product's cost very high, compared to the same products that are imported, which leads to lowering the Libyan products' competitiveness in the local markets. 
The result from the analysis indicates that the most obstacles that prevent change implementation are suppliers, logistics, the organizational culture and special conditions, intractable accounting and finance practices. Further, some of the interviewees believe that the change needs a long time compared to the benefits, and lacks in the whole change structure or necessary elements However, the smallest percentage is the most thought that it is difficult to apply any new system with the current condition. On the other hand, the researcher believes that there is a big chance for changing and a new manufacturing adoption if the industry sector overcomes the main problems, which are; overseas suppliers that consider the main problem. This is followed by a high implementation cost, and a lack of management and government support difficultly to recognize benefits and lack of technology.

Finally, the majority of answers indicate that the solutions to those difficulties are; local suppliers because the material availability will be the only way to implement any new manufacturing system, followed by the management support to the application.

Some of them believe that creating a transportation strategy and a technology has a great impact, but may lead to an increased cost, which is contrary to the objectives of the application. These opinions agreed with Elbishti, 2015 results in the study titled the degree of JIT in MOAM in Libya. Elbishti wrote that some of the logistics are an obstacle to the adoption, because, any problem in the delivery of the material will affect the production stages. As a result, that leads to the lack of availability of the manufacturing items, which will affect the ability to meet the demand of the client, and the inability to meet the market demand which sometimes leads to the closure of the factory.

\section{Acknowledgements}

My deepest gratitude for support and encouragement throughout my research work goes to the manager of Libyan Economic Research Centre, Dr. Hatim Zgeel, for his advice and making this work an invaluable learning experience, also for his willingness to support me through my working life.

\section{Conflicts of Interest}

The author declares no conflicts of interest.

\section{References}

[1] Dalton, J.T. (2013) A Theory of Just-in-Time and the Growth in Manufacturing Trade. Research Paper, LMU Munich, Germany. https://doi.org/10.2139/ssrn.2292177

[2] Greb, E. (2009) Is JIT Manufacturing the Right Prescription? Pharmaceutical Technology, 33.

[3] Hirano, H.Y. (2009) JIT implementation Manual. CRC Press, USA.

[4] Nair, M.A. (2010) Relationship between Just-in-Time Manufacturing Practices and 
Performance: A Meta-Analytic Investigation. Journal of Operations Management, 28, 283-302. https://doi.org/10.1016/j.jom.2009.10.002

[5] Mohamed, E.K. (2017) Main Inventory Management Elements on Reducing Storage Cost. Asian Journal for Business and Management, 5, 54-61. https://doi.org/10.24203/ajbm.v5i2.4651

[6] Mohamed, E.K. (2105) The Availability of JIT's Elements in Mineral and Asphalt Industries in Libya and There Relation with Cost and Competition. Ph.D. Thesis, University UTHM, Malaysia.

[7] Adeyemi, S. (2010) Just-in-Time Production System (JITPS) in Developing Countries the Nigerian Experience. Journal of Social Sciences, 22, 145-152. https://doi.org/10.1080/09718923.2010.11892795

[8] Kaneko, J. and Nojiri, W. (2008) The Logistics of Just-in-Time between Parts Suppliers and Car Assemblers in Japan. Journal of Transport Geography, 16, 155-173. https://doi.org/10.1016/j.jtrangeo.2007.06.001

[9] Elbishtawi, S.H. and Elmatarna, G.H.F. (2005) Just-in-Time System and Its Effect on Making Strategies Decision. Ph.D. Thesis, Al Albeat University, Jordon.

[10] Hokoma, R.A. (2010) The Current Awareness of JIT Techniques within the Libyan Textile Private Industries: A Case Study. International Journal of Materials and Textile Engineering, 4, 886-889.

[11] Kumar, V. (2010) JIT Quality Management, Concepts and Implications in Indian Context. International Journal of Engineering Science and Technology, 2, 40-50.

[12] Kumar, B.S. and Sampath, V.R. (2012) Garment Manufacturing through Lean Initiative. An Empirical Study on WIP Fluctuation in T-Shirt Production Unit. International Journal of Thinking, 13, $4 \mathrm{p}$.

http://www.europeanjournalofscientificresearch.com

[13] Abdaliah, A.B. and Matsui, Y. (2007) The Relationship between JIT Production and Manufacturing Strategy and Their Impact on JIT Performance. POMS 18 th annual conference Dallas, Texas, USA, 4-7 May, 2007.

[14] Abu Ata, (2005) A Study of Factor Related to Applicability of Just-in-time (JIT) in Garment Industry in Jordan. Master's Thesis, University of Jordan, Amman, Jordan.

[15] Javed, Z.H., Farooq, M. and Akram, S. (2010) Cost-Push Shocks and Inflation: An Empirical Analysis from the Economy of Pakistan. Journal of Economics and International Finance, 2, 308-312. https://doi.org/10.5430/ijfr.v2n1p57

[16] Jose, O. (2008) Strategic Human Resource Management, Small and Medium Sized Internship and Strategic Partnership Capability. Research Paper, University Of Pennsylvania, Philadelphia, USA.

[17] Polito, T. and Watson, K. (2006) Just-in-Time under Fire: The Five Major Constraints upon JIT. The Journal of American Academy of Business, 9. 